\title{
IRONIA I NIHILIZM. FIGURA BIBLIOTEKARZA W POSŁUCHANIU U LUCYPERA JÓZEFA SĘKOWSKIEGO
}

\author{
Słowa kluczowe: biblioteka, Józef Julian Sękowski, ironia, czarny romantyzm, nihilizm
}

Keywords: library, Józef Julian Sękowski, irony, Dark Romanticism, nihilism

Popychany on był do tego zwrotu - całym szeregiem okoliczności i przyczyn poprzednich, a związanych z sobą łańcuchem żelaznej konieczności; co więcej - jakby nieodzownością samej natury własnej.

Aleksander Jabłonowski ${ }^{1}$

\section{Wprowadzenie $^{2}$}

Józef Julian Sękowski (1800-1858) jest jedną z tych postaci, bez analizy której trudno w pełni zrozumieć postawy Polaków pierwszej połowy XIX wieku. Zapisał się w historii Polski jako narodowy renegat, zdrajca, a czarną legendą przewyższa go chyba tylko Szczęsny Potocki. Zarazem jest to do dziś znany i ceniony przez historyków literatury - pisarz rosyjski, prozaik, publicysta, redaktor o niezaprzeczalnych zasługach dla tej literatury, twórca i redaktor najpopularniejszego w swoim czasie pisma rosyjskiego „Bibliotieki dla cztienja”3.

${ }^{1}$ Aleksander Jabłonowski, „Orientalista Sękowski w korespondencji z Lelewelem. Studium na tle listów orientalisty osnute", in idem, Pisma, vol. 7: Rzeczy polskie, z przedmową J.K. Kochanowskiego (Warszawa: Skł. gł. E. Wende, 1913), 166.

${ }^{2}$ Tekst powstał w ramach projektu NPRH „Kontynuacja krytycznych edycji wybitnych, zapomnianych dzieł XIX-wiecznej polskiej literatury romantycznej w NSW «Czarny Romantyzm» w XII tomach” (2018-2021).

${ }^{3} \mathrm{O}$ osiągnięciach Sękowskiego jako redaktora i pisarza vide Daria Ambroziak, Każdy baron ma swoja fantazję. Józef Sękowski. Polak z pochodzenia, Rosjanin z wyboru (Opole: Wydawnictwo Uniwersytetu Opolskiego, 2007); Danuta Piwowarska, „Twórczość Józefa Sękowskiego. Zapomniana karta z dziejów rosyjskiej prozy XIX-wiecznej”, in Polacy w życiu kulturalnym Rosji, ed. Ryszard Łużny (Wrocław - Warszawa - Kraków - Gdańsk - Łódź: Zakład Narodowy im. Ossolińskich, 1986). 
Sękowski ma bardzo wyrazisty, stereotypowy konterfekt; kreował świadomie swoimi wyborami życiowymi wyrazistą biografię mityczną, mitobiografię. Jest ona inna w zależności od punktu patrzenia, który wyznacza narodowość obserwatora. Dla Polaków to zdrajca, cynik, oszczerca powstania listopadowego, wymieniony przez Mickiewicza w prelekcjach paryskich z imienia i nazwiska jako zaprzaniec ${ }^{4}$. Dla Rosjan: Polak z pochodzenia, któremu wielu nie ufało do końca, najwierniejszy z wiernych poddanych cara, zdolny prozaik-prekursor, wybitny żurnalista i orientalista.

U źródeł rozbieżności w ocenie pisarza i uczonego leży decyzja Sękowskiego, który po 1832 roku wyrzekł się swej polskości, z szyderstwem odniósł się do upadku i konsekwencji powstania listopadowego, ogłosił się Rosjaninem, zaczął też pisać tylko po rosyjsku.

W istocie dla nikogo, kto śledził losy Sękowskiego od młodości, jego renegactwo nie mogło być zaskoczeniem. Sękowski uchodził za człowieka genialnych zdolności, poliglotę, młodego orientalistę, uczonego. Przyjaźnił się z Lelewelem, wywarł wpływ na twórczość autora Dziadów w okresie jego pobytu w Rosji (choć Mickiewicz nie uległ sile jego inteligencji, odnosił się doń z dystansem). Na wyjazd Sękowskiego do krajów Wschodu (1819-1821) społeczeństwo Wilna i Warszawy zorganizowało zbiórkę funduszy. Kiedy jednak „geniusz” powrócił z wyprawy, odmówił przyjęcia posady profesora nadzwyczajnego na Uniwersytecie Wileńskim, przyjmując, spełniającą jego ambicje, profesurę zwyczajną w Petersburgu. Gorliwie za to pełnił funkcję cenzora i wizytatora ${ }^{5}$.

Sękowski przeszedł do historii i kultury Polski i Rosji jako postać antypatyczna, ale... wybitna. Cynik, karierowicz, sługus carski - to stereotyp polski. Wpływowy, lecz cyniczny intrygant, krypto-Polak, zabijający przeciwników słowem i donosem - to stereotyp rosyjski. Podejrzewano powszechnie, iż jest donosicielem carskiej policji.

Co ma z tym wspólnego motyw biblioteki? Postać bibliotekarza? Jak sądzę, bliższa analiza jednego z najgłośniejszych utworów Sękowskiego - Postuchania u Lucypera (i/lub Wielkiego postuchania u Lucypera, kwestię tytułu zaraz wyjaśnimy) - pozwoli przybliżyć znaczenie i źródła postawy pisarza.

Wypada dodać rzecz oczywistą: twórczość Sękowskiego/Senkowskiego powinna być badana ze szczególną wnikliwością także przez badaczy polskich, polonistów (a nie tylko przez polskich i rosyjskich rusycystów) ${ }^{6}$. Do 1832 roku

${ }^{4}$ Vide Adam Mickiewicz, Dzieła, vol. 9: Literatura stowiańska. Kurs drugi, ed. Julian Maślanka, trans. Leon Płoszewski (Warszawa: Czytelnik, 1997), wykład XIX, 251.

${ }^{5}$ Ludwik Bazylow, Polacy w Petersburgu (Wrocław - Warszawa - Kraków - Gdańsk - Łódź: Zakład Narodowy im. Ossolińskich, 1984), 169-175.

${ }^{6}$ Pierwsze od ponad stu pięćdziesięciu lat wydanie, zawierające obie wersje Postuchania u Lucypera i Fantastyczne podróże barona Brambeusa ukazało się w 2017 roku w Naukowej Serii Wydawniczej „Czarny Romantyzm”. Vide Józef Sękowski, Fantastyczne podróże barona Brambeusa, 
Sękowski jest postacią tak wkorzenioną w środowisko polskie - od Towarzystwa Szubrawców przez środowisko uniwersyteckie wileńskie i petersburskie - że trudno bez niego pomyśleć opowieść o dziejach kultury polskiej lat 1820-1832. Intrygujący, dający do myślenia jest przypadek tak jednoznacznej apostazji narodowej, wyrażającej się w agresywnym stosunku do polskości, Polaków, polszczyzny. Podkreślę: do 1832 roku Sękowski jest twórcą polskim, którego pisma powinny zostać zebrane i krytycznie wydane, począwszy od publicystyki wyrastającej z inspiracji Towarzystwa Szubrawców, a na ostatnich tekstach petersburskich kończąc ${ }^{7}$. Tymczasem pisarz budzi zainteresowanie głównie rusycystów. Doczekał się monografii rusycystycznych w Związku Radzieckim, Stanach Zjednoczonych i ostatnio w Polsce. Szczególnie amerykańska praca Louisa Pedrotti z 1962 roku w sposób obszerny dokumentuje polskie korzenie, polską formację intelektualno-estetyczną Sękowskiego ${ }^{8}$. Powinno to stać się wyzwaniem także dla polonistów.

Kim był ów człowiek, skrywający się to za maską diabelskiego bibliotekarza, to za figurą samego Lucypera? Podpisujący swe rosyjskie prace pseudonimem „barona Brambeusa”, a w światowych badaniach znany jako Józef Sękowski, Osip Senkovskij, Osip Senkovsky? Niewątpliwie dłuższe obserwowanie jego poczynań, analizowanie pism pozwala na stwierdzenie, iż w życiu i twórczości był typem kameleona. Postacią niejednoznaczną w najgłębszych tego słowa wymiarach, także etycznym. Znane i często przypominane są słowa jedynego Polaka, który po 1832 roku „przyjaźnił się” w Petersburgu z Sękowskim, lekarza, memuarysty Stanisława Morawskiego (1802-1853). I on jednak, poniżony publicznie przez Sękowskiego jako Polak, zerwał tę znajomość, pozostawiając ambiwalentny konterfekt geniusza cynizmu, nihilizmu i ironisty, człowieka bezinteresownie złośliwego:

Jeśli przypuścić, że Bóg w niezbadanych wyrokach swoich stwarza człowieka na to, żeby źle robił prosto dla miłości złego; żeby jego ruchy, jego czyny, jego mowa, jego myśli, jego pisma zawsze w żółciowym brodziły oceanie; żeby był zły con amore, z rozkoszą... a przy tym obdarzony różnostronnym, najtrafniejszym, najzabawniejszym, najdotkliwszym, najjadowitszym, genialnym dowcipem i jedną z najrozleglejszych nauką - to rodak nasz Sękowski palmę by za to przynajmniej w całej Słowiańszczyźnie otrzymał ${ }^{9}$.

wstęp Jarosław Ławski i Joanna Dziedzic, ed. Małgorzata Burzka-Janik et Jarosław Ławski (Białystok: Wydawnictwo Prymat, 2017).

${ }^{7}$ Vide Zdzisław Skwarczyński, „Wstęp”, in „Wiadomości Brukowe”. Wybór artykułów, ed. Zdzisław Skwarczyński (Wrocław: Zakład Narodowy im. Ossolińskich, 2003).

${ }^{8}$ Cf. Veniamin Kawierin, Baron Brambeus: istorija Osipa Sienkowskiego, żurnalista, redaktora „Bibliotieki dla cztienia” (Moskva: „Nauka”, 1966); Louis Pedrotti, Józef-Julian Sękowski. The Genesis of a Literary Alien (Berkeley and Los Angeles: University of California Press), 1965; Daria Ambroziak, op. cit.

${ }^{9}$ Stanisław Morawski, op. cit., 23. 
Jak tu wskazano, odpowiedź na pytanie o groźny fenomen Sękowskiego przybliżyć może analiza jego ostatniego polskiego i zarazem pierwszego rosyjskiego utworu. W 1832 roku w „Bałamucie Petersburskim” Sękowski opublikował opowiadanie Postuchanie u Lucypera. Zostało ono przyjęte jak najgorzej przez Polaków. Zawierało bezprzykładne szyderstwo z klęski powstania listopadowego oraz osobisty atak na niedawnego przyjaciela Sękowskiego - Joachima Lelewela, z którym przez lata pisarz utrzymywał korespondencję. Zwróćmy uwagę na tytuł: to Postuchanie u Lucypera. Tymczasem słowniki i bibliografie przywołują najczęściej inny tytuł, lecz jakby z wahaniem, czy jest prawidłowy: Wielkie postuchanie u Lucypera! $!^{10}$ I to ostatnie Wielkie postuchanie... było w Polsce drukowane w 1835 roku (z anonimową przedmową tłumacza), a następnie dwukrotnie w 1862 roku wznawiane w napiętej politycznie atmosferze tuż przed powstaniem styczniowym ${ }^{11}$. By sprawę skomplikować: istnieje też rosyjski tekst pod tytułem Bolszoj wychod u Satany, opublikowany w 1833 roku $^{12}$. Jest to przekład-parafraza utworu polskiego, czyli Postuchania u Lucypera opublikowanego w „Bałamucie". Mamy więc dość osobliwą konstelację tekstów.

Postuchanie u Lucypera, napisane po polsku i opublikowane w polskim piśmie, to utwór graniczny, oddzielający postawę Sękowskiego jako polskiego renegata od postawy gorliwego sługi cara, sui genesis nadgorliwego prozelity, „super-Rosjanina”. Zarazem jednak jest to tekst dojrzały, to swoiste apogeum intelektualne Sękowskiego. Horyzont rozpoznań świata, jaki zarysowuje on w Postuchaniu u Lucypera, nie zostanie już przezeń przekroczony. Nawet pisane po rosyjsku i znakomite Fantastyczne podróże barona Brambeusa $(1833)^{13}$ nie przynoszą już pogłębienia oglądu świata i człowieka. To w Postuchaniu u Lucypera pisarz - niedawny tłumacz fragmentów Boskiej Komedii Dantego ${ }^{14}$ - zszedł na samo dno świadomości, do ostatniego kręgu, który nazwałbym Kręgiem Szyderstwa, Ironii i Nihilizmu.

${ }^{10}$ Vide „Sękowski Józef Julian (1800-1858)”, in Dawni pisarze polscy od poczatków piśmiennictwa do Młodej Polski. Przewodnik biograficzny i bibliograficzny, vol. 4: $S-T$ (Warszawa: Fundacja Akademia Humanistyczna et IBL PAN, 2003), 34-36.

${ }^{11}$ Vide Józef Sękowski, Wielkie postuchanie u Lucypera. Z pism Barona Brambeusa (Warszawa: J. Wróblewski, 1835); idem, Wielkie postuchanie u Lucypera. Z pism Barona Brambeusa (Warszawa: B.J. Salzstein, 1862), 56; wydanie nowe: Warszawa 1862.

${ }^{12}$ Józef Sękowski, Balszoj wychod u Satany, trans. z polskiego na rosyjski autora (Petersburg: „Nowosielje”, 1833), 129-186.

${ }^{13}$ Osip Senkovskij, Fantasticzeskije putieszestwija barona Brambieusa (Petersburg: 1833); ed. 2: Petersburg 1835.

${ }^{14}$ Vide Agnieszka Kuciak, Dante romantyków. Recepcja „Boskiej Komedii” u Mickiewicza, Stowackiego, Krasińskiego i Norwida (Poznań: Wydawnictwo Naukowe UAM, 2001); eadem, „„Hańba dla zdrajcy, którego pożeram». Adam Mickiewicz, Józef Sękowski i przekładanie Dantego”, in Księga Mickiewiczowska. Patronowi Uczelni w dwusetna rocznice urodzin 1897-1998, ed. Zofia Trojanowiczowa, Zbigniew Przychodniak (Poznań: Wydawnictwo Naukowe UAM, 1998). 
Tę najciemniejszą świadomość - niezwykle niepokojącą - oddają losy gości u Lucypera, pana świata; poddanych, wśród których jest i diabelski bib li o t e k a r z B ib li o m a n o s. W głębokim sensie jest on też lucyferycznym kucharzem, diabeł Sękowskiego żywi się bowiem... książkami. W literackim piekle Polaka, który właśnie w 1832 roku przeistacza się w Rosjanina, wszystko jest żałosne i straszne, a jeśli śmieszne, to w sposób przykry, sardoniczno-sarkastyczny. Wczytanie się w lucyferyczne księgi, wpatrzenie w Wielkiego (Lucyper) i małego (Bibliomanos) Bibliotekarza odsłania potęge szyderstwa pannihilisty i panironisty, które to szyderstwo - daleko wykraczając poza nasze przyzwyczajenia ufundowane przez polski stereotyp zdrajcy i rosyjski stereotyp carskiego konfidenta - mierzy we wszystko i we wszystkich: w człowieka, Rosjanina, Polaka, powstańca, i... cara.

\section{Bibliotekarz Lucypera}

Opowiadanie Postuchanie u Lucypera oparte zostało na schemacie fabularnym oficjalnej audiencji, przyjęcia interesantów przez panującego lub urzędnika ${ }^{15}$. Ponieważ jednak przyjmujący jest tu równocześnie nadzorcą przyjmowanych, audiencja ma w sobie coś z sytuacji przesłuchania, rewizji, kontroli. Oba schematy - popularne w literaturze - wyraźnie wskazują (ale bez żadnych konkretów historycznych) na sytuację w państwie, gdzie włada monarcha absolutny. Jego maską jest Lucyper, książę ciemności, pan pokus i piekieł, wzywający swoich diabłów-ministrów na posłuchanie. Opowiadanie jest tak skonstruowane, iż mówi o sytuacji uniwersalnej (kuszeni ludzie), a równocześnie inkrustowane takimi odwołaniami literackimi (literatura francuska, polska, rosyjska, aluzje historyczne), iż nie sposób nie dostrzec, że znajdujemy tu karykaturalny obraz Europy, jej kultury, pogrążonej w „rewolucjach” w Belgii, krajach niemieckich i Polsce. Z pozoru jest to pochwała absolutyzmu: diabelskiego i/lub (na planie aluzyjno-alegorycznym semantyki tekstu) carskiego. Piszę: z pozoru, bo Lucyper - absolutny władca - jest tu figurą i śmieszną, i straszną, a przede wszystkim okrutną, zarządzającą masą ministrów-łajdaków-diabłów, którzy pokornie stawiają się przed nim, w tym diabeł bibliotekarz. „Obowiązek nadwornego marszałka” sprawuje tu „Lukullus, który umarł z niestrawności” (PuL, 89) ${ }^{16}$.

${ }^{15}$ Oczywiście, można tu przywołać wiele utworów z motywem audiencji i zarazem posłuchania, rewizji: Rewizora Gogola (pisze go od 1835 roku) po Listy z Rosji Astolphe'a de Custine. W literaturoznawstwie rosyjskim wskazywano także na silne u Sękowskiego inspiracje pisarstwem Honore de Balzaca.

${ }^{16}$ Sękowski szczodrze szafuje erudycją - w opowiadaniu roi się od przedstawicieli kultury antycznej, średniowiecznej lub najnowszej. Wyraźnie widać, że pisarz chce też zabłysnąć znajomością dzieł najnowszych, modnych oraz wiedzą orientalistyczną. 
Właściwie w każdym przypadku posłuchanie przebiega w ten sam sposób: diabeł indaguje ministrów w sprawie postępów ich kusicielskiej pracy, za każdym razem albo wyróżnia podwładnego, albo skazuje na wymyślne, okrutne kary. Całość przedstawiona jest $\mathrm{z}$ intencją satyryczną, która posługuje się ironią, karykaturą, sarkazmem aż po groteskowe przekształcenie. Nie staje się jednak groteską w pełni. Co dla tematu pracy najważniejsze: ów tekst rozpoczyna się od satyrycznego ataku na książkę, na literaturę i na bibliotekę jako „skarbnicę” fałszywej wiedzy, z inspiracji której ludzie wszczynają pozbawione sensu rebelie ${ }^{17}$.

Postuchanie u Lucypera jest konstrukcją złożoną, jeśli chodzi o wymowę: to oczywiście skandaliczny atak na powstanie listopadowe, ale jeszcze bardziej na wszelkie ruchy rewolucyjne w Europie i na świecie. To pamflet na literaturę - zarówno klasycystyczną, jak i romantyczną. Style i mody literatur ukazane są tu jako formy trujących lub irracjonalnych idei. W jeszcze szerszym zakresie jest to atak na naukę, a w roli kozła ofiarnego występują tu teologia, filozofia idealistyczna i właściwie wszelkie formy myślenia, które, jak sugeruje narrator, nie przynoszą pożytku poznawczego. Nie unieważniając wszystkich wskazanych poziomów znaczeniowych, przypatrzmy się temu, co o książce, bibliotece, bibliotekarzu pisze Sękowski.

W jego opowiadaniu absolutnym i ostatecznym, choć nienachalnie się przejawiającym, kreatorem sensów jest bowiem nie Lucyper, lecz narrator. Jest on ironistą, kpiarzem, w końcu cynikiem, który wyczarowuje okrutno-błazeński spektakl posłuchania: „Już to dawno wiadomo - powiada narrator - z dzieł księdza Naramowicza SJ, że diabli w dzień śpią, a wstają dopiero po nieszporach, o godzinie piątej lub szóstej” (PuL, 89) ${ }^{18}$. Piekło jest tu odwróconym światem ludzkim: ironicznym antyświatem, królestwem nocy, zła, swego rodzaju podziemnym monstrualnym antyświatem. Panują w nim: potęga absolutnego władcy i służalczość quasi-metafizycznych diabłów. To świat ludzki à rebours. Tam, u ludzi - przejawia się pragnienie dobra i wiedzy, zapisanej w księgach zebranych w bibliotekach. Tu - włada pragnienie zła. Dlatego właśnie przebudzony wieczorem Lucyper zaczyna panowanie od posiłku - złożonego z książek, które zjada jak „sucharki”:

A wiecież co to za sucharki? Król czartów nic tak nie lubi chrustać sobie z swoją kawą, jak oprawne w byczą skórę księgi wierszem i prozą, in-folio, in-quarto i in-octavo; tomy logik i psychologii, encyklopedii i słowników; zbiory badań, przez które nic nie wybadano, historii, w których nic nie powiedziano, retoryk, które niczego nie nauczyły, rozpraw, które niczego nie dowiodły;

${ }^{17}$ Oczywiście jest to motyw stary jak kultura oparta na książce: motyw ataku na fałszywą uczoność, którą symbolizują księgi. Obecny także w literaturze Oświecenia, by przywołać Monachomachię Ignacego Krasickiego.

${ }^{18}$ Ksiądz Naramowicz - zapewne ironiczne przekształcenie nazwiska ks. Grzegorza Piramowicza SJ, jezuity, pisarza, działacza oświatowego, być może skontaminowanego z nazwiskiem ks. bp. Adama Naruszewicza SJ, pisarza, „polskiego Horacego”. Obaj byli gorącymi zwolennikami Oświecenia, które Sękowski wyszydza tak samo jak romantyzm. 
a najbardziej, epopeje i wszelkie grube poemata, opowiadawcze, dydaktyczne, filozoficzne, romantyczne, prozaiczne itd., itd. Lecz od niejakiego czasu postrzegł, że ten rodzaj ciasta sprawiał mu straszne zatwardzenie żołądka; kazał przeto nadal przynosić sobie do kawy tylko nowe romanse historyczne i modne powieści, nowe melodramy, nowe tragedie w pięciu i sześciu obrazach, rozmyślania poetyczne, messenianki i ballady, jako daleko lżejsze, nie tak gęsto drukowane, obficie przełożone białymi stronicami, rozrzadzone kropkami i winietkami i prawie tak strawne, jak sam czysty papier [PuL, 89].

Również ten pomysł nie jest nowy. Karykaturalna, satyryczno-groteskowa bibliofagia to odwrotność i parodia aktu lektury jako duchowej inspiracji. $\mathrm{Na}$ dalszym planie jest to również (czy świadoma) parodia aktu natchnienia boskiego, które czasem, jak u Romana Melodosa, przedstawione było jako połknięcie ksiąg (symbolicznego) ${ }^{19}$. Lucyper łyka księgi jak sucharki. Zjedzone książki zostają natychmiast zapomniane w świecie ludzkim. Sam Lucyper jawi się jako parodystyczno-ironiczna transpozycja „niosącego światło”, „Światłonoścy” (lucis ferre - nieść światło). To niosący ciemność, ale raczej nie metafizyczny książę ciemności, lecz żałosny, antropomorficzny władca. W pewnym sensie jest on figura „,cezaromorficzną” w sensie ironicznym: parodiuje cara, cesarza, króla ${ }^{20}$. Również jego „bibliotekarz” - diabeł Bibliomanos - to nie diabeł ogarnięty manią czytania ksiąg, lecz figura tumaniąca ludzkość fałszywymi obietnicami, jakie rzekomo książka i biblioteka niosą:

- Gdzie diabeł Bibliomanos?... krzyknął Lucyper groźnym głosem, od którego całe zatrzęsło się piekło.

Natychmiast wyskoczył na środek sali mały, chudy, skrzywiony jak znak pytania, diabełek w starym kapeluszu z szerokimi brzegami, i pokłonił się nisko panu. Był to jego bibliotekarz, czart niezmiernie uczony, przedtem niemiecki Gelehter, co umiał na pamięć tytuły wszystkich książek, znał wszystkie wydania, pamiętał ile stronic w każdym tomie i gardził tym, co na stronicach, jako belletryzmem.

- Łotrze! to nieświeże sucharki, rzekł Lucyper grzmiącym tonem.

- Najciemniejszy panie, odpowie drżący diabełek: świeższych dostać nie mogłem. Prawda, że dzieła są nieco dawne, ale za to wydania nowe, tylko co spod prasy [PuL, 89-90].

Sękowski celowo używa stereotypu „diabła”-Niemca i Niemca jako „uczonego" (der Gelehrter). W jego świecie wszystko podlega prawu ironizowania: nawet stereotyp i ironia. Bibliomanos jest dostarczycielem pokarmu dla Lucypera-bibliofaga: modnych dzieł i klasyki.

Zauważmy: ten skierowany przeciw nauce, książce, bibliotece spektakl rozpętuje pisarz, który uchodzić może za erudytę swoich czasów, znający kilka lub

${ }^{19} \mathrm{O}$ motywie tym vide Aleksander E. Naumow, Biblia w strukturze artystycznej utworów starocerkiewnostowiańskich (Kraków: UJ, 1983), 32.

${ }^{20} \mathrm{Z}$ tradycji zachodnioeuropejskiej vide Jean-Paul Roux, Król. Mity i symbole, trans. Katarzyna Marczewska (Warszawa: „Volumen” et „Bellona”, 1998); z tradycji wschodniosłowiańskiej vide Borys A. Uspienski, Wiktor M. Żywow, Car i Bóg. Semiotyczne aspekty sakralizacji monarchy w Rosji, trans. Henryk Paprocki (Warszawa: Państwowy Instytut Wydawniczy, 1992). 
kilkanaście języków, w tym wszystkie klasyczne, orientalne. Pisarz znający także turecki, arabski, uczy się ponadto chińskiego ${ }^{21}$. A jednak u Sękowskiego już w 1832 roku, gdy stał się on poważanym wykładowcą uniwersyteckim, nauka jest wyszydzoną obietnica prawdy. Podziwiano profesora na Uniwersytecie Petersburskim za erudycję, ale bano się go panicznie ${ }^{22}$. Sam Sękowski nie pozostawiał złudzeń. Drobny wtręt każe myśleć o nim jak o człowieku nieznoszącym rzemiosła, którym się para:

Trafnie wymierzona księga przeleciała na wskroś przez czczą potępieńca głowę, tak właśnie, jak cały kurs uniwersyteckich nauk zwykł przelatywać przez puste mózgownice paniczów - żadnego po sobie nie zostawując śladu, - i upadła z tyłu na posadzkę [PuL, 91; podkreśl. - J.Ł.] $]^{23}$.

Studenci okazują się więc natrętami; czytelnicy sforą zwiedzionych i otumanionych przez mody literackie i filozoficzne ofiar diabła. Na cenzurowanym w tym krótkim opowiadaniu staje cały dorobek ludzkości: od antyku (Arystoteles jako przedmiot kpin), przez wieki średnie (teologia, Awicenna, uczoność bernardyńska) po współczesność; by wspomnieć listę modnych dzieł, zmieniającą się w kolejnych wersjach „posłuchania”. Niezadowolony Lucyper - skazuje jednak Bibliomanosa na okrutną karę:

Diabełek podszedł, cały trzęsąc się ze strachu. Lucyper złapał go za ucho, podniósł na powietrze jak piórko, włożył w sążnisty tom dzieł Arystotelesa po grecku, które lubi czytać, kiedy cierpi świerzb w ogonie, co u diabłów odpowiada naszym spazmom - zamknął księgę i sam siadł na niej. Biedny strażnik piekielnej książnicy, pod ciężarem olbrzymich pośladków pana Erebu, spłaszczył się natychmiast, między twardymi stronicami klasycznej próby, na kształt suchego liścia mięty. Lucyper skazał go na służenie mu za zakładkę do książki przez lat 1111 [PuL, 90].

W scenach karania, jakie przewijają się przez cały utwór, wolno widzieć parodię scen posłuchań u władcy, cara, a nawet scen sądu królewskiego. O ile jednak sąd królewski polega na wymierzaniu sprawiedliwości, to sąd diabelski jest cyniczną grą, sadystyczną drwiną z karanych i wszystkich tych, którym udzieliła się wiara w książki, ich przesłanie, idee wolności i sprawiedliwości. Przywołany

${ }^{21}$ Vide Franciszek Nowiński, Polacy na Uniwersytecie Petersburskim w latach 1832-1884 (Wrocław: Zakład Narodowy im. Ossolińskich, 1986); Krzysztof Stachowski, „Władysława Kotwicza niepublikowany Rzut oka na losy orjentalistyki w Polsce (1938)", Ling Varia, no. 214 (2012).

${ }^{22}$ Ludwik Bazylow, op. cit., 174: „Pierwsze czternastolecie działalności Sękowskiego na gruncie petersburskim było «pełne blasku». Zbierał nieustannie laury jako uczony i profesor, mimo że ze znanych już względów nie budził sympatii. Od 1 stycznia 1834 r. zaczął wydawać swój słynny miesięcznik «Bibliotieka dla cztienija» i poświęcał mu się coraz bardziej, wiele też na jego łamach pisał. Mniej więcej od 1836 r. zaczął ograniczać swoje zajęcia uniwersyteckie, gorzej się do nich przygotowywał, w 1847 - wspominano już o tym - odszedł z uniwersytetu zupełnie”. Ten przypis nie odnosi się do tego, że „Sękowskiego bano się panicznie”.

${ }^{23}$ Podobnie ironiczne przytyki pod adresem studentów znajdziemy w Fantastycznych podróżach barona Brambeusa. 
Belzebub otrzymuje więc zadanie znalezienia nowego bibliotekarza. Ma nim być postać do złudzenia przypominająca Joachima Lelewela:

Po czym, zawołał Belzebuba, swego oblubieńca i wezyra, i rzekł:

- Znajdź mi jakiegokolwiek sprytniejszego potępieńca na miejsce tego pedanta. Można będzie powierzyć mu bibliotekarstwo tymczasowe; gdyż mam zamiar oddać ten urząd temu sławnemu bibliotekarzowi, co niedawno sprawił na ziemi szaloną zawieruchę. Musimy go za to przyzwoicie nagrodzić; mój zaś wielki mistrz rokoszów, diabeł Astaroth, który się z nim poznajomił i zaprzyjaźnił, powiada, że on zdatny tylko na opylacza i układacza książek. Skoro zawita w nasze strony, przyjmij go grzecznie - rozumiesz? - i natychmiast mianuj moim bibliotekarzem. Trzeba jednak przykuć go w bibliotece na mocnym łańcuchu, żeby mi czasem nie zrobił w piekle rewolucji i konstytucyjnych nie zaprowadził budżetów [PuL, 90].

W ten sposób - w odwróconym do góry nogami świecie lucyperycznym - potwierdzona zostaje rola książki i biblioteki jako rozsadników buntowniczych idei. Sceptycyzm Sękowskiego sięga dalej. Książka jest rozsadnikiem fałszywych obietnic, iluzji epistemologicznych, którymi próbują mamić ludzkość konkurenci Lucypera: ludzie Kościoła, filozofowie, poeci. Nieprzypadkowo żarliwy, ironiczny atak na książkę trwa w Postuchaniu u Lucypera aż do końca. Zaraz po Bibliomanosie posłuchania dostąpi diabeł architekt Don Diego da Bufalo, dawny budowniczy kościołów. Omówiwszy plac remontu piekła, Lucyper skazuje jednak na potępienie nie diabła architekta, lecz szacowne dzieła filozofii idealistycznej, przez które ,żadne światło przebić się nie zdoła”:

Lucyper pomyślał, poskrobał się w głowę i rzekł:

- Nie ma pieniędzy!.. Ciężkie teraz czasy ostatnie trzy chwalebne rewolucje na ziemi kosztowały mi niesłychanie wiele złota, a cena papierów spada diabelnie na giełdach... - Tu, jął się kopać ręką w czopie i wyciągnął zeń Kurs filozofii Schellinga; obejrzał go, przepatrzył i cisnął nim w łeb architektowi, mówiąc:

- Na! weź tę książkę i zaklej nią szparę w sklepieniu: przez tę filozofią żadne światło przebić się nie zdoła [PuL, 91].

I to nie wyczerpuje jeszcze lucyferycznej biblio-awersji: po kolei o niszczącym wpływie książek, gazet, ulotek mówią „naczelny diabeł spraw małżeńskich, pierwszy lord-diabeł dziennikarstwa, wielki kanclerz literatury i wielki mistrz rewolucji”. Pojawiają się przed władcą w odwróconym porządku - w piekle bowiem wszystko dzieje się na wspak.

Lecz sensy utworu są u prozaika budowane w ustalonym porządku. Sękowski, wybitny kontynuator satyrycznych tradycji wileńskiego Towarzystwa Szubrawców i ich „Wiadomości Brukowych”, uruchamia w utworze ten typ ironii, która ma genezę oświeceniową: w dziełach epoki, z której wyrasta Sękowski, pełniła ona rolę narzędzia chłostającego wady, oświecała przez odsłanianie, niszczenie wszystkiego, co nierozumiane, zacofane. Taka oświeceniowa ironia odsłaniała wtedy właściwy ideał człowieka. W ogóle - odsyłała do ideału, kazała budować, 
zmieniać. Pisarz maksymalizuje efekty owej niszczącej wiarę w książkę i erudycję ironii, lecz nie wskazuje na żaden pozytywny projekt kultury, cywilizacji, władzy ${ }^{24}$.

Książnica Bibliomanosa jest monstrualną kuchnią zapomnienia, przygotowującą idee zawarte w książkach i pismach wszelakich do przejścia w stan nieistnienia. Co by to mogło znaczyć? Znaczy „nic”. Jak się wydaje, u Sękowskiego ironia służy tylko ironizowaniu, to znaczy niszczeniu iluzji, któremu towarzyszy piekielny śmiech satysfakcji. To dlatego w Postuchaniu u Lucypera jedynym tekstem godnym aplauzu Lucypera okazuje się „bilans małżeńskich grzechów”:

- Kiedyż to tak łatwo, najciemniejszy panie, złapać największych mędrców i najsurowszych filozofów na przynętę słodkiego ciałka!... Oto przynoszę waszej piekielnej mości bilans małżeńskich grzechów za cały przeszły miesiąc. W ciągu tego miesiąca, za mym pośrednictwem, na całej powierzchni ziemi i należnego do niej księżyca,

pokłóciło się małżeństw $33,333,333$

pobiło się $\quad 8,888,888$

rozwiodło się $\quad 1,111,111$

zdradziło się wzajemnie $77,777,777$

summa summarum: $\quad$ 999,999,999 [PuL, 101].

Być może to za daleko posunięty wniosek, lecz, sądzę, że Sękowski przeciwstawia: książce i bibliotece - ciało, pragnieniom poznawczym i religijnym - przyjemność, nieszczęściu i biedzie orędowników wolności, buntowników - bogactwo i władzę posłusznych. Zza całej opowieści o wielkiej pasji bibliotekarskiej i bibliologicznej Lucypera przebija grymas nihilisty: nic nie ma. Ani nauka, ani wiedza, ani tym bardziej religia czy kultura nie są wartościami ocalającymi godność istnienia. Przeciwnie: ich iluzje i w konsekwencji fiasko obnażają niemal zupełny bezsens wszelkich usiłowań. Pisarz nie wyprowadza z takiej konkluzji postulatów heroicystycznych, nie orzeka o tragizmie istnienia. Odwrotnie: każe spełniać się ambicjom, których siedliskiem są ego, rozum, ciało; ambicjom prowadzącym do władzy i przyjemności ${ }^{25}$. W tym świecie nie grozi nikomu bellum omnes contra omnes, bowiem gwarantem bezpiecznego realizowania ambicji są władca, cesarz, król, car. Zwornik tego świata. Panujący.

Sękowski kreuje świat bez nadziei, które żywi większość ludzi - poznawczych i religijnych, egzystencjalnych i społecznych ${ }^{26}$.

${ }^{24}$ Cf. Jarosław Ławski, „Ironia”, in Stownik polskiej krytyki literackiej 1764-1918. Pojęcia - terminy - zjawiska - przekroje, ed. Józef Bachórz, Grażyna Borkowska, Teresa Kostkiewiczowa, Magdalena Rudkowska, Mirosław Strzyżewski, vol. 1: $A-M$ (Toruń - Warszawa: Wydawnictwo Naukowe UAM, 2016).

${ }^{25} \mathrm{~W}$ tym znaczeniu Sękowskiemu bliżej jest do postawy nowoczesnego libertyna-dworaka.

${ }^{26}$ Cf. Mikołaj Sokołowski et Jarosław Ławski, ed., Historia i nihilizm. Studia z literatury XIX i XX wieku (Białystok - Warszawa: Wydawnictwo Uniwersyteckie „Trans Humana”, 2009) - tu: Zbigniew Kaźmierczak, „Dyskurs o śmierci: jego bezsiła, jego mistyfikacje, jego chwała”; Michał Januszkiewicz, „Pożegnanie z metafizyką”, 603-617, 629-667. 
W najważniejszym dziele pisarza Fantastycznych podróży barona Brambeusa - pisanych już tylko po rosyjsku, wyd. w 1833 roku, a po polsku przełożonych i wydanych w 1840 roku - pesymizm zdaje się być jeszcze pogłębiony. Bibiotheca mundi to tutaj tekst bez sensu. Tekst, któremu sami nadajemy znaczenia. Hieroglify z syberyjskiej jaskini - w zależności od tego, kto je czyta - okazują się fascynującą opowieścią o zagładzie świata przez kometę (to odczytanie uczonego filologa), albo bezsensowną formacją geologiczną, złożoną w „,hieroglify” przez naturę $\mathrm{z}$ minerałów:

- Ja powiedziałem, że to hieroglify dlatego, żeś mi zawrócił głowę swym Szampolionem mówił doktor.

- A ja widziałem w nich historią potopu, dlatego żeś mi zaprzątnął głowę swymi teoriami o wielkich zburzeniach ziemi - odpowiedziałem.

- Chciałbym jednak wiedzieć - dodał doktor - jakim sposobem wyprowadziłeś sens, tłumacząc prostą igraszkę natury?

$\mathrm{Na}$ co, rozumie się, odpowiedziałem doktorowi:

- Nie moja w tym wina, że z głupich igraszek natury, według gramatyki Szampoliona, można wywieść sens dość prawdopodobny! ${ }^{27}$

Józef Sękowski nieprzypadkowo w Posłuchaniu u Lucypera uczynił księgę, bibliotekę i bibliotekarza głównym obiektem ataku. Nie lekceważąc wątku antypowstaniowego, wskażmy jednak, że to w furii ataku skierowanego przeciw bibliotece i książce wyraża się w swej istocie filozoficzne zwątpienie. Niesie ono za sobą spustoszenie, niewiarę, cynizm, ateizm. Zwątpienie posługujące się satyrą, ironią, sarkazmem, groteską i makabreską. Odrzuca pocieszenie, diagnozę tragiczną. Proponuje nihilizm, którego uzasadnieniem - jako czynnikiem usprawiedliwiającym podtrzymywanie tej postawy - jest żądza władzy, przyjemności, zaszczytu. Nihilizm hedonisty i sybaryty posługuje się książką jako narzędziem osiągania mocy władzy, ale też gardzi biblioteką jako skatalogowanym muzeum iluzji poznawczych i estetycznych. Bibliotekarza osadza w roli uwodziciela ludzkości.

Szlachetna tradycja XIX-wiecznego obrazowania biblioteki i pracy bibliotekarza zostaje tu wykpiona ${ }^{28}$. Biblioteka nie ma sensu, sens ma tylko posługiwanie się biblioteką i bibliotekarzem, książką i motywem biblioteki, bibliotekarza i książki. Nihilistyczne koło się zamyka. Takie są prawa piekieł, gdzie wszystko dosłownie, a nie ironicznie, jest i nie jest, jawi się, by zniknąć, przejawia, by przejawić niebyt. Zanim do sali na przesłuchanie wkroczy bibliotekarz, narrator zdradza:

${ }^{27}$ Józef Sękowski, Fantastyczne podróże barona Brambeusa, trans. W.O. [Witalis Olechowski], vol. 2 (Warszawa: S.H. Merzbach, 1840), 169.

${ }^{28}$ Cf. Monika Drożdżewicz, „Obraz księgarza w literaturze polskiej drugiej połowy XIX wieku”, Bibliotekarz Podlaski, no. 23/24-25 (2012); Dawid Maria Osiński, „Ciało w bibliotece”, in Bibiotheca mundi. Studia bibliologiczne ofiarowane Janowi Leończukowi, ed. Jarosław Ławski et Łukasz Zabielski (Białystok: Wydawnictwo Prymat, 2016), 399-474. 
Skrzypnęły przeraźliwie wielkie żelazne podwoje sypialnego pokoju pana ciemnych przybytków; Lucyper wszedł do sali, i zasiadł na tronie. Obecni upadli na twarzi krzyknęli: vivat! - ale ich głosu nie było słychać; bo to wszystko są cienie, i krzyk ich jest tylko cień krzyku (PuL 89; podkreśl. - J.Ł.).

\title{
Przezroczysta czerń
}

Kiedy zmarł pisarz-Lucyper, co zdawało się niemożliwe, znikł lęk przed nim. A z nim podziw, do którego władzą talentu zmuszał. Ani w serii „posłuchań u Lucypera”, ani w Fantastycznych podróżach barona Brambeusa, nie znajdziemy idei lub uczucia, w poszukiwaniu których chcielibyśmy ponowić zachwyt ich pierwszą lekturą.

Nie napiszę więc: nic tam nie ma. Muszę napisać: „nic” tam jest. Lub: tam, w tych książkach, znajdziemy „prawdziwe” i jedyne w swoim rodzaju „nic”. „Najciemniejszy pan”, diabeł, jest tu więc prawodawcą takiego nurtu „czarnego romantyzmu", w którym nawet czerń straci moc z powodu braku światła i bieli. Jest to świat, gdzie żałosny diabeł pali ludzi jak karty papieru wydarte z ksiąg, których jego zdaniem nie warto było pisać...

Teraz Wasza piekielna Ciemność wyłącznie i samowładnie panuje nad całą literaturą, nad wszystkimi tworami dowcipu ludzkiego. Wszystkie tchną nieczystą siłą, wszyscy gadają przez diabła, i my nigdy nie byliśmy w większym znaczeniu na ziemi, jak dzisiaj. Zwaliliśmy na koniec Olimp grecki: Jowisz upadł, a na jego tronie zasiadł Lucyper, pan nasz i dobrodziej. Ludzie, za moją sprawą, śpiewają tylko piekło i zbrodnią [PuL, 100].

Jakiż sens w takim świecie miałaby biblioteka?

\author{
IRONY AND NIHILISM. THE LIBRARIAN FIGURE \\ IN AN AUDIENCE WITH LUCYPHER BY JÓZEF SĘKOWSKI
}

Sum mary

The subject matter of the present article is the image of library and librarian in a forgotten short story by a Polish-Russian writer Józef Julian Sękowski (1800-1858). Sękowski is known in Polish literature as a multi-talented orientalist and polyglot, who changed his national identity in 1832 and began to write only in Russian. In the history of Russian literature he is famous for Library for Reading and Fantastic Voyages of Baron Brambeus, an ironic-grotesque work, which was precursory in Russian prose. Until 1832 Sękowski was, however, a Polish writer. His last significant work was An Audience with Lucypher published in a Polish magazine Bałamut Petersburski (Petersburgian Philanderer) in 1832 and immediately translated into Russian by Sękowski himself under the title Bolszoj wychod u Satany (1833). The library and librarian presented by the author in this piece are a caricature illustration proving his nihilistic worldview. Sękowski is a master of irony and grotesquery, yet the world he creates is deprived of freedom and justice and a book in this world is merely a threat to absolute power. 